\title{
Revisiting the Narrative Powers of the Global South through The Travels of Dean Mahomet
}

\author{
Tanutrushna Panigrahi \\ Assistant Professor, Humanities Education, International Institute of Information \\ Technology, Bhubaneswar, Odisha. Email: tanutrushna@iiit-bh.ac.
}

\begin{abstract}
The Travels of Dean Mahomet is a 1794 autobiographical travel narrative of an Indian, Dean Mahomet, recalling his years as a camp-follower, servant, and subaltern officer in the East India Company's army between 1769 and 1784. Mahomet's Travel includes his journey in India and to the West in which the Indian view of the British rule in India has been recorded. A rereading of the text from the Global South literary perspectives, both contests and agreements, unfolds how the text engages both in colonial and postcolonial concerns simultaneously and create spaces for new literary encounters. The book's power to negotiate with postcolonial accounts; to demonstrate the existence of multilateral voices, and a multiculturalist's northsouth dialogues comes both from the act of travel and the act of writing. The text plays the victimological narrative take/approach; colonial oppression and anticolonial resistance binaries, non-Eurocentric perspectives and subsequently moves beyond the radical dichotomy of the colonizer and the colonized and the imperialist/nationalist divide of the eighteenth century. More importantly, through the very act of writing it provides a shift of focus from postcolonial to the Global South. A significant literary voice from the non-western location needs to be revisited, established and re-established. This paper aims to read the travel narrative of Dean Mahomet in this context, to explore how the non-European perspectives demonstrate the existence of multilateral voices that participated in the process of imperialism.
\end{abstract}

Keywords: Global South, Colonial India, Cultural Hegemony, Eurocentric, Orientalism

\section{Introduction}

The Travels of Dean Mahomet is an eighteenth century autobiographical travel narrative written by an Indian, Dean Mahomet, recounting his journey through mostly northern India as a campfollower, servant, and subaltern officer in the East India Company's Bengal army from 1769 to 1784. It was published in the year 1794 in Cork while Mahomet was living as an immigrant in Ireland and was intended for two types of readers, firstly as a representation of colonial India to the elites around him in England and Ireland and secondly, as a travel guide to the European travellers to India. Mahomet's travelogue presents an Indian's view of the British conquest of India and conveys the vital role taken by Indians in the colonial process. It thus engages both in colonial participation and postcolonial concerns simultaneously, and create spaces for new literary encounters. The long original title of Mahomet's narrative The Travels of Dean Mahomet, a Native of Patna in Bengal, through Several Parts of India, while in the Service of the Honourable The East India Company. Written by Himself, in a Series of Letters to a Friend. In Two Volumes indicates the text's $s$ multiple performances, forms and the author's multiple identities; creating complex layers of perspectives that feed the literary preoccupations of the global south. Levander and Mignolo theorize the Global South as:

(c) AesthetixMS 2020. This Open Access article is published under a Creative Commons Attribution Non-Commercial 4.o International License (http://creativecommons.org/licenses/by-nc/4.o/), which permits non-commercial re-use, distribution, and reproduction in any medium, provided the original work is properly cited. For citation use the DOI. For commercial re-use, please contact editor@rupkatha.com. 
... place of struggles between, on the one hand, the rhetoric of modernity and modernization together with the logic of coloniality and domination, and, on the other, the struggle for independent thought and decolonial freedom... the places where decolonial emancipations are taking place and where new horizons of life are emerging. (Levander \& Mignolo, 2011, p.4).

Moreover "the Global South" may reframe old questions in such a way as to produce new knowledge, that it may open up new vectors of enquiring exploration that do not merely reveal terrains previously ignored, but generate novel ways of inhabiting them.(West-Pavlov,2018,p.19) The lineaments of The Travels and the global south literary theorization meet at many points and propose a rereading of the text from the global south literary aesthetics and the reframed perspectives. If the southern dialogue within the text, the global south literary ideologies, southern sense of modernity and the southern struggle for "decolonial emancipations" make the points of discussions/form an important framework of a critical reading of The Travel, it is not difficult to understand how the non-European perspectives of the author demonstrate the existence of a literary voice that is both participatory and emancipatory in the process of imperialism.

\section{Travelogue, Identity and Representation in Mahomet's Travels}

Edward Said, in his highly influential work, Orientalism, asserted that Western hegemony emphasized on a unilateral cultural representation of Asia:

The power to narrate, or to block other narratives from forming and emerging ...constitutes one of the main connections between...culture and imperialism.... From the beginning of Western speculation about the Orient, the one thing the Orient could not do was to represent itself.( Said, 1979,p. xiii, p. 283)

The Western organization of the power and the powerless, to be able to represent oneself and one's culture is one major critical quotient in the Mahomet's text. His travel memoir is an early representation of non-western locations and cultures in the British imperial process. He would be successful, Mahomet seemed to understand, only when he could negotiate the many perception issues regarding identity of the subject of an empire in the east-west relationship of power in the British colonial scene. Mahomet's authorial voice, that of a secular, cultural insider and his unusual, significant text as a powerful testimony of the construction of resistance, performed multiple roles and provided multiple identities. Mahomet's narrative "represented" his India, in his voice, "written by himself", to an English audience. The long title of the book presupposes the several dynamics of the text that will shape up several contests relating to hegemony, power and identities. Indeed it was the prevalent literary fashion of the travel writing in the seventeenth and eighteenth century Europe to keep long titles. Mahomet's joining the European literary fashion is again a cultural resistance to domination; becomes a shifter from the margin to the centre.

While Mahomet provides an insider's perspectives and while he attempts to secure a world view (especially the English) through the text into the colonial India, he upsets the expectations of being very rigid about the position he takes on the imperial presence or the reverse, unlike other travel narratives on India of the same time. John-Henry Grose's $A$ Voyage to the East Indies, with Observations on Various Parts There (1757), Jemima Kindersley's Letters from the Island of Teneriffe, Brazil, the Cape of Good Hope and the East Indies (1777) and William Hodge's Travels in India During the Years 1780, 1781, 1782, and 1783 (1793) provide biased views of 
the Indian culture and the eighteenth century Indian realities. These eighteenth-century European writers “...use familiar binary categories of pagans and barbarians for Indians in the descriptions of Indian culture rather than adopting a more nuanced presentation of the religious and cultural heterogeneity of India" (Narain, 2009, p. 694). The European politics of representation in the travel writing played an important role in establishing cultural hegemony and a metaphorical relation between the writer and the colonizer during high imperialism. (Spurr, 1993: Said, 1978; Pratt, 1992).Mahomet's Travels is a colonial representation that is neither rebelling nor criticising the East India Company who is his employer; neither exalting nor exoticising the Indian culture that the readers expect, and its representations of the British in India, while occasionally critical is not the narrative of radical questioning on the Imperial dominance and power. Instead, the author "assessed the virtues and flaws of both British and Indian cultures, each of which did much to shape his identity."(Fisher, 1997, p.xix). An explanation for adopting such an approach can be found in a possibility of Joseph Emin's influence. Emin was an Armenian immigrant to India and then to England. Mahomet read Joseph Emin's autobiography and took the text published in England in 1792 as the immediate model. Emin wrote his travel experience in India as a soldier in the Company's army and appreciated the British. "Mahomet's publication closely follows Emin's publication and marks the beginning of Asians writing to define their identity and place in Britain." (Narain, 2009, p.695).

But Dean Mahomet while being sympathetic to the British, demonstrating his allegiances to the Company in several occasions, wrote a text that "in many ways performs such a task of undoing previously fixed notions about India and offering an alternative picture."(Narain, 2009, p.711). Mahomet's Travels does not strictly accommodate the postcolonial binaries, moves beyond them and steps into the global south idea of "decolonial emancipation." Commonly read and understood as a variant of postcolonialism, global south references subscribe to the victimological approach. The Travels intends similar take and perspectives but moves beyond the radical dichotomy of the colonizer and colonized, the imperialist and the nationalist of the eighteenth century, and more importantly, through the very act of balancing provides a shift in focus from postcolonial to the global south "to palliate the stasis that appears to beset postcolonial studies." (West-Pavlov, 2018, p.16). Dean Mahomet's presumably simple travelogue assumes complex engagements in balancing between the status of a marginalised insider both in India and England and negotiating the postcolonial accounts very much being in the process of imperialism, demonstrating the existence of multilateral voices and a multiculturalists' north-south dialogues that the global south literary concerns find a powerful point of debates.

\section{Mahomet's Travels from Postcolonialism to Global South}

The narrator of the Travels might be seen as representing what Abdul Jan Mohamed has called "hegemonic colonialism" a state in which "the natives accept a version of the colonizer's entire system of values, attitudes, morality, institutions, and.., mode of production." They seem, in other words, to be speaking as the hegemonically colonized "other," as though his mind itself had been colonized; he seems to have developed, in the words of Edward Said, "a consciousness that assumed the subordination of a designated inferior Other"(Narain, 2009, p.695). Mahomet's travelogue is a product of his desire to create a text that follows the European practice of cultural representation. When Dean Mahomet "determined to write a travel narrative about India, he studied earlier travel narratives and copied parts of them" because he "found aspects of their work worthy of emulation... he paraphrased or directly lifted material from them without attributiona practice today termed plagiarism"(Fisher,1997,p.138-9). Mahomet's coming in contact with the 
Europeans and their travel writings and making use of it opens possibilities to be read as what Pratt calls the "contact zones", the "social spaces where disparate cultures meet, clash, and grapple with each other, often in highly asymmetrical relations of domination and subordination" and the process she calls "transculturation" in which the "subordinated or marginal groups select and invent from materials transmitted to them by a dominant or metropolitan culture. While subjugated peoples cannot readily control what emanates from the dominant culture, they do determine to varying extents what they absorb into their own, and the uses to which they put it" (Pratt, 1992, p.19).When we apply Pratt's theory it brings the text into the postcolonial trajectory and all its fixation, but the global south reading pushes the text away from the "deempiricizing and depoliticizing road." (West-Pavlov, 2018, p. 16). A more polyvalent critical reading of the text brings us to several other arguments. It is important to argue that Mahomet also had other "contact zone." He was in the cultural contact of, interactive with and was influenced by IndoPersian literary traditions. The travel writings or safarnamas grew out of the European contacts with the Persian and the Muslims. The Travels of Mirza Abu Taleb Khan in Asia, Africa, and Europe during the Years 1799, 1800, 1801, and 1802, written by Abu Taleb Khan, who met Mahomet in Ireland in December 1799, Shigurf Namah-I-Velaet, Or, Excellent Intelligence Concerning Europe; Being the Travels of Mirza Itesa Modeen in Great Britain and France by I'tisan al-Din (Mirza), and Mirza Sheikh I'Tesamuddin's The Wonders of Vilayet: Being the Memoir, Originally in Persian, of a Visit to France and Britain in 1765 are travelogues which visibly have similarities with Mahomet's The Travels.

Mahomet appropriated several features of these Persian texts into his book but the authorial position is reverse. The Persian travelogue writers describe the awe and wonders of foreign lands or Vilayet as outsiders visiting the foreign countries whereas Mahomet is an author occupying an ambivalent (both) position; he is a marginal insider as well as an outsider in both countries. In India "While his Muslim relatives accepted him as an honored guest at their domestic rituals, he nevertheless stood as an outsider to their world by virtue of his attachment to the British. Some Indians in the countryside assaulted him as part of their resistance to British control; others rescued him and gave him shelter. In his life and writings, he revealed the social and cultural tensions inherent within that substantial class of Indians which fostered British colonial expansion over India"(Fisher,1997, p.xiv). In England and Ireland he stood separate from the people "in origin, color, and culture...his situation remained quite different... His literary achievement, Travels, received the endorsement of hundreds of Ireland's leading citizens, proof that they regarded him as a man of culture. Yet he remained someone quite apart from Irish society at the time." And in London Dean Mahomet and his family, "combining as they did both Indian and Irish identities, would have had a particularly difficult time establishing their place in London." (Fisher, 1997, p. 135, 145)

Mahomet as a bi-national and an author had to meet several challenges and complexities before occupying the role of a transformed and transculturated author with a distinct voice from both hegemonic and non-hegemonic locations. "His travelogue invites multiple layers of interpretations and therefore exemplifies Jacques Derrida's evocation of the multivocal other" (Narain, 2009, p.697). He is an Indian, a Muslim, a European Other, a British soldier, and an immigrant to Ireland. He had to call attention through all these voices to assert his identities. While he has to transact with each of these identities and move beyond the fixed connotation he had to disentangle from several binaries; colonizer/colonized, Indian/British, native/immigrant, imperialist/nationalist, local/global, cultural centre/cultural margin and finally Eastern/Western. The text thus transcends the fixations and the binaries; creates a separate and independent 
literary space, not western not non-western, and the dialogue between the north and the south takes place, a global south space that may not give us access to "subalterns" who cannot speak, but " in which speech can be invented. It does not reveal or recover; rather, it triggers processes of creative renewal" (West-Pavlov, 2018, p. 8). In the act of "speech-as-self-identification," Mahomet creates a voice that does not condemn the white oppressors nor elevate his own cultures above others, thus, transcending hierarchy and changing the positions of the pronominal $I$ representing the position of a dominating addressor and you (his White readers) are his addressees in the position of the dominated. He, on the contrary uses the pronoun "we" to describe himself and the Europeans. (Clarkson, 2013) Global South aesthetics with its inclusive permissions and fluid literary architecture allows an interpretation of Mahomet's identity and narrative voice to be an independent, new and creative one. The text functions at two levels, as a new corrective statement of the global south and a benign representation of Indian culture of the eighteenth century British colonial India.

\section{Language, Identity and Global South in Mahomet's Travels}

Mahomet writes a travelogue in the English language, uses the epistolary style and an autobiographical voice. It can be attributed to two important objectives, or one can say, imperatives; first, Mahomet followed what was the current literary fashion. Travelogue in the epistolary form was the contemporary choice, fashion and was popular "in Britain at the time, but was unknown in his natal culture, his choice recapitulated his self-location as an intermediary, drawing upon an English form to represent his Indian background for an elite anglophone audience" (Fisher, 1997, p.xx). The politics of his adopting the fashionable English literary tradition of the eighteenth century in which the figure of a traveller is central exploring countries and continents and presenting accounts and experiences, is to establish a narrative individuality of a speaking subject who interrogates the physical and cultural boundaries. The narrative is written in a series of thirty eight constructed letters to an imaginary European friend, dedicated to a colonel in the East Indian Company's Bengal Army, W. A. Bailie. (Image 1) In each of his letters he provides extensive descriptions of different subjects: his lineage and ancestry, Indian topography, military, various battles that were fought during this period, the political terrain, political disputes and, the social and cultural landscape of India. He addresses his target audience -- the Irish and British readers -- in Letter I and expresses his desire to satisfy them with an unusual kind of literary work:

Since my arrival in this country, I find you have been very anxious to be made acquainted with the early part of my Life, and the History of my Travels: I shall be happy to gratify you; ...that the gratification of your wishes, is the principal incitement that engages me to undertake a work of this nature...(Fisher, 1997, p.34).

The opening lines suggest two kinds of compliances, one, a willingness to satisfy the master and another, an attempt to diffuse the supremacy of an agency by the device of an intellectual equaliser, that is a text.

"Travel is not a word that can be easily evoked to talk about the Middle Passage, the Trail of Tears, the landing of Chinese immigrants, the forced relocation of Japanese Americans, or the plight of the homeless" observes bell hooks. "From certain standpoints, to travel is to encounter the terrorizing force of white supremacy" (hooks, 1992, p.173). Mahomet's travels both physical and metaphorical are not only about the "middle passage" or a "relocation"; neither are experiences of crossing of one geographical border to entering into another. His traveller and 
immigrant situation busts two standpoints/stereotypes in the European discourse on the colonized. One, his "actual, figural, textual, and symbolic travels between India and Britain" is "representative of the two worlds he inhabits and travels between in his text" (Narain, 2009, p. 696) and in the process challenges the "white supremacy" in a reverse way. Second, he further negotiates what Said terms "positional superiority" of the westerner :"The scientist, the scholar, the missionary, the trader, or the soldier was in, or thought about, the Orient because he could be there, or could think about it, with very little resistance on the Orient's part" (Said, 1979, p.7).The image of a traveller, following Said's coinage, similarly, in the European travel writing and the literary imagination is a white, male, European, travelling to the non-western locations as an observer of exotic spectacles and "westerners are travelers, and nonwesterners are travelees--static spectacle or hapless pawns"(Murphy, 1994, pp. 551-568). Mahomet is both a travelee and a traveller, and he moves between positional inferiority and positional superiority.

The link between identity creation and the autobiography form of the narrative is complex in the case of Dean Mahomet. While he makes an inclusive representations of cultural differences and cultural encounters between the East and the West, he has to shape and calibrate several identities and assume a range of positions to overcome other complexes, perceptions and stereotypes associated with the white-coloured, ruler and ruled, invader and invaded relationships. "Indeed, a reading of his travelogue troubles purist notions of colonized subjectivity that is seen in binary terms-as either resistant or complicit" (Narain, 2009, p.699). Mahomet attributes it to his human connection with Baker who replaced the father figure in Mahomet's life. He tells that he joined the East India Company's Bengal Army as a camp follower of his own accord after his father's death because as a young boy of eleven he was impressed when he first saw British army officers, especially Baker. He migrated to Ireland because Baker was leaving India and he thought "I should suffer much uneasiness of mind, in the absence of my best friend." (Fisher, 1997, p.124).His initiation to the world began with Baker and his maturing ideologies were oriented to his life and experience with Baker. Therefore, it is not surprising that Mahomet's allegiances were equally extended to the East India Company as to his country. Another important social factor is Mahomet's lineage that goes back to Central Asia and his ancestors' migration to the Mughal kingdom in India and their elitist position during the Mughal and then the British period. Neither his ancestors, nor his father, had placated any nationality or race issue since it was the early phase of the British Imperial expansion and also his forefathers followed family tradition.

Travels uses English language with a significant mix of Hindustani languages: Hindi, Persian, local dialects of Hindi and Bengali and there are references to other Indian languages of the time. It can be read as a result of both English hegemonic impositions and Mahomet's desire for self-expression, resistance and solidarity. On the language texture of the narrative, one finds embedded a mosaic of languages. Mahomet seems to have been transculturated to the greatest extent in this context, neither assimilating to the linguistic culture of the empire, nor to that of the subordinated. Although Michael Fisher believes that Mahomet elaborately quoted from "high English literature" and used "Latin quotations (which he did not translate into English, thus presupposing the erudition of both his readers and himself)," he partially explains the phenomenon (Fisher, 1997,p. XIX). Mahomet is the eighteenth century global south writer in the league of global south literary authors as Chinua Achebe, Salman Rushdie and Chimamanda Adichie and several others in using English in the hybrid form as well as belief in linguistic freedom for the expression of culture and identity. In one of her interviews, Adichie said: 
"I do not believe in being prescriptive about art. I think African writers should write in whatever language they can... The important thing is to tell African stories... I come from a generation of Nigerians who constantly negotiate two languages ...My English-speaking is rooted in a Nigerian experience and not in a British or American or Australian one. I have taken ownership of English" (Adichie, 2016, pp.147-148).

She reminds us of Rushdie saying

"I don't think it is always necessary to take up the anticolonial or is it post-colonial? Cudgels against English. What seems to me to be happening is that those peoples who were once colonized by the language are now rapidly remaking it, domesticating it, becoming more and more relaxed about the way they use it assisted by the English language's enormous flexibility and size, they are carving out large territories for themselves within its frontiers" ( Rushdie, 2014, pp.19-20).

Dean Mahomet exercised a choice that does not have to be interrogated from postcolonial ethics and principles relating to the dominator's language or that one of the dominated. Once again, he transcends the limiting territories and borders of cultural hegemony. His linguistic ideologies make him an early cosmopolitan in reaching all new linguistic frontiers and crossing the borders. Not only in the linguistic expressions but in other dynamics Mahomet's book is one of the earliest Indian texts to achieve cosmopolitanism and can be read in the light of global south and world literature. Mona Narain discusses Travels from the literary concepts globalism and cosmopolitanism and writes:

Mahomet's self-presentation and his text then support the ideology of early modern cosmopolitanism that one can be a citizen of the world. In doing so, he inverts and appropriates the famous, quintessentially English assertion by Joseph Addison's Mr. Spectator, "I am a Dane, Swede, or French-Man at different times, or rather fancy myself like the old Philosopher, who upon being asked what Country-man he was, replied, That he was a Citizen of the World," ironically written in a context that roundly affirms England as the center of all the world and the Englishman as most suited for this role. (Narain, 2009, p. 695).

Mahomet's centre is not in England, it is in multiple locations, locations where he lived and wrote: Ireland, England and India. He wrote from the shifting cultural centres with an equally sincere, honest, if not always authoritative, truthful voice. Mukoma Wa Ngugi at Cornell University, commenting on the objectives of Global South, very interestingly argues that the Global South project at Cornell with scholars like Satya Mohanty and others perceive that there is no single centre, or they are everywhere. They want to break free from triangulating theory through the West like deconstruction, hybridity etc. because those "end up trapped in the same dialectic from which they are trying to break free" Their project "has the immediate goal of breaking this linkage in order to generate debates that have no built-in hierarchies," that Ngu "gi wa Thiong'o's Globalectics (2012) talks about; the challenge is to "break out of the "prison houses" of language, the ivory tower, and the imaginary centers. In this way, globalectics offers us one way to organize "knowledges" coming from the Global South" (Ngugi, 2013, pp. 36-39).

\section{Conclusion}

Mahomet presents different engravings in his Travels ( here only three images) to project his several personalities; an Indian gentleman in western outfits, a nawab, an Indian Army officer and 
an Indian courtier in an Indian ruler's procession, a shampooing surgeon in Brighton, husband of an Irish rich woman, and an English and Irish immigrant. As an example, on the frontispiece of the book he writes "Dean Mahomet, an East Indian." His coming of age from an eleven year old upper class Muslim boy to a European immigrant via several others is the earliest example of a bildungsroman in Indian literature. As Mona Narain correctly observes:

Mahomet's Travels is a text that presents a variety of verbal constructs for the reader: the Indian cultural context from the point of view of an upper-class Muslim minority male, the viewpoint of a soldier in the Company's Bengal Army, and, retrospectively, the point of view of the Indian immigrant in Ireland. These verbal constructs coexist simultaneously, creating complex layers of identification and meaning. (Narain, 2009, p.703).

The complex layers are contradictory and diverse, overlapping, adopting, including and excluding at the same time. A bewildering and fascinating crisscrossing of Oriental and Western cultural, historical and linguistic experiences are the major literary merit of the text. We are reminded of what Edward Said mentioned in Culture and Imperialism (1993):

[W]e have never been as aware as we are now of how oddly hybrid historical and cultural experiences are, of how they partake of many often contradictory experiences and domains, cross national boundaries... Far from being unitary or monolithic or autonomous things, cultures actually assume more "foreign" elements, alterities, differences, than they consciously exclude.( Said, 1993,p.15)

\section{Illustrations}

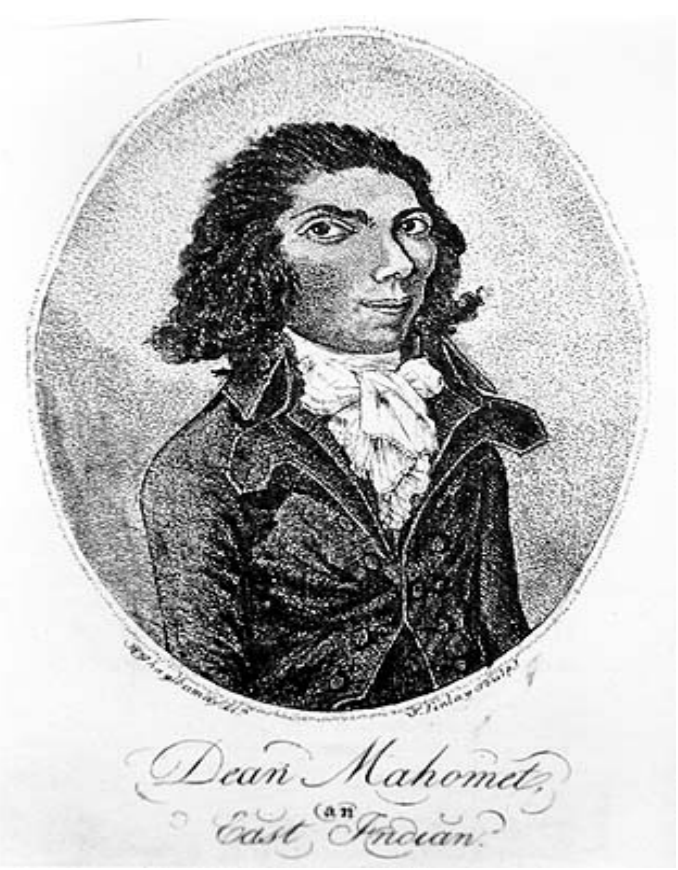

Figure 1: Dean Mahomet, an East Indian (Mahomet, Travels, frontispiece) 


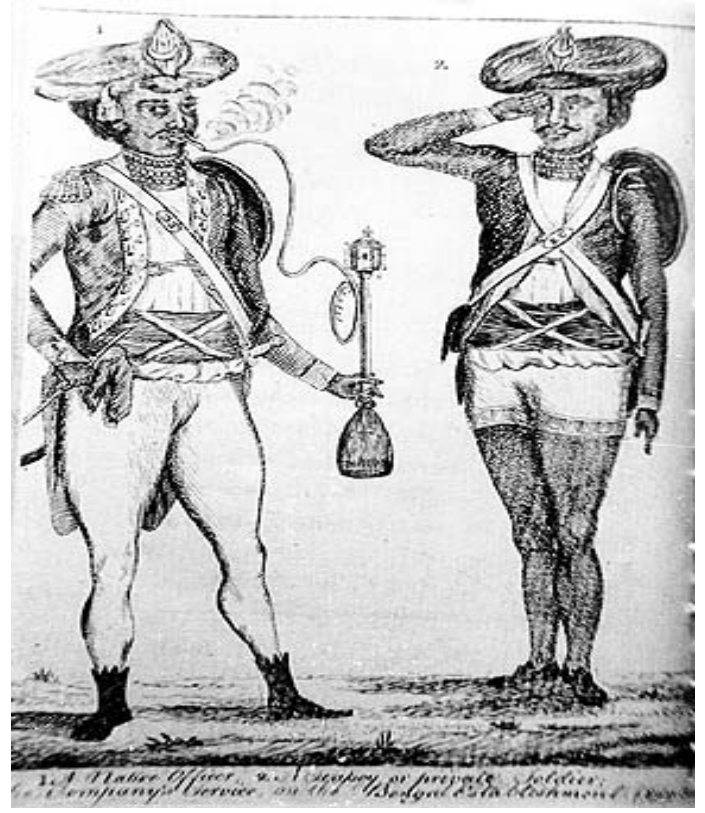

Figure 2: A Native Officer (1.); A Seapoy or private soldier (2.), in the Company's Service, on the Bengal Establishment (Mahomet, Travels, Letter XVI).

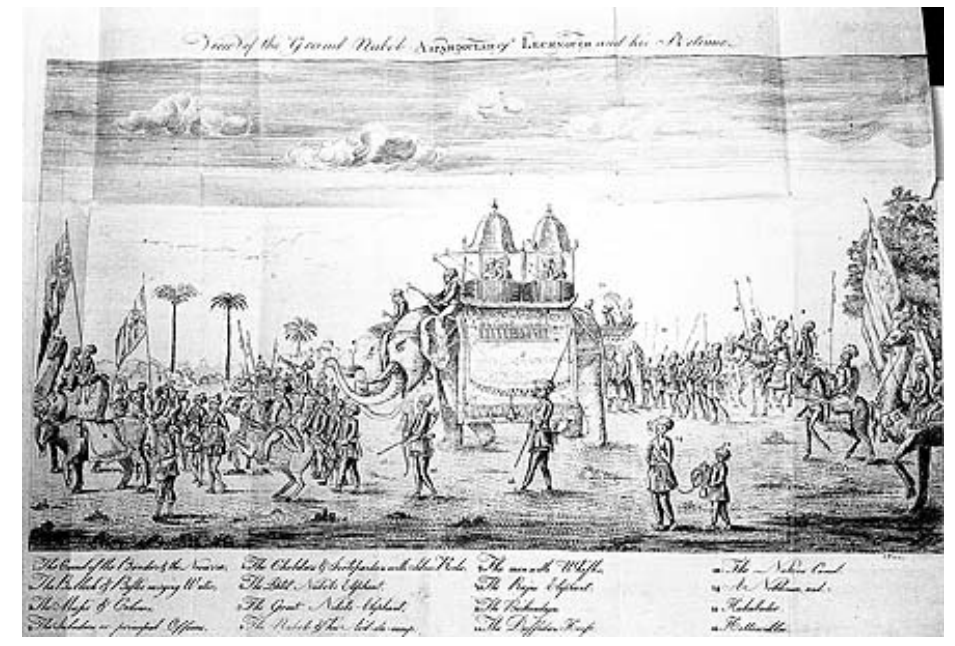

Figure 3: View of the Grand Nabob Aspahdoulah of Lechnough and his Retinue (Mahomet, Travels, Letter XXIII).

\section{References}

Azodo, A. U. (2008). Interview with Chimamanda Ngozi Adichie: Creative writing and literary activism. Women's Caucus of the African Literature Association.

Clarkson, C. (2014). Drawing the line toward an aesthetics of transitional justice. New York: Fordham University Press.

Hooks, bell. (2015). Black looks: race and representation. New York: Routledge.

Levander, C., \& Mignolo, W. (2011). Introduction: The Global South and World Dis/Order. The Global South,5(1), 1-11. doi:10.2979/globalsouth.5.1.1 
Mahomet, S. D., \& Fisher, M. H. (1997). The Travels of Dean Mahomet: an eighteenth-century journey through India. Berkeley, CA: University of California Press.

Murphy, G. (1994). Olaudah Equiano, Accidental Tourist. Eighteenth-Century Studies,27(4), 551-568. doi: $10.2307 / 2739439$

Narain, M. (2009). Dean Mahomet's Travels, Border Crossings, and the Narrative of Alterity. SEL Studies in English Literature 1500-190049(3), 693-716. doi:10.1353/sel.0.0070.

Ngugi, Mukoma Wa (2013). Breaking Out of the Prison House of Hierarchy. World Literature Today, 87 (3), 36-39. doi: 10.7588/worllitetoda.87-3.0036 (Ngugi-Wa-Thiongo-and-Salman-Rushdie-on-English). Retrieved from http://mr-shannon.com/wp-content/uploads/2014/o5

Pratt, M. L. (1992). Imperial Eyes: Travel Writing and Transculturation. New York \& London: Routledge.

Said, E. W. (1979). Orientalism. New York: Vintage Books.

Said, E.W. (1993). Culture and Imperialism. New York: Alfred A. Knopf.

Spurr, D. (2004). The Rhetoric of Empire: Colonial discourse in journalism, travel writing, and imperial administration. Durham: Duke University Press.

West-Pavlov, R. (2018). The Global South and Literature. Cambridge: Cambridge University Press. 